\title{
Healthcare workers' knowledge, risk perception, safety-relevant practices, and work situation during the COVID-19 pandemic: A quantitative survey from Switzerland
}

\author{
Marco Riguzzi;, Shkumbin Gashi, Iren Bischofberger \\ Careum Research, Careum School of Health, Zürich, Switzerland
}

Received: January 28, 2021

Accepted: February 19, 2021

Online Published: March 14, 2021

DOI: $10.5430 /$ jnep.v11n $7 \mathrm{p} 19$

URL: https://doi.org/10.5430/jnep.v11n7p19

\begin{abstract}
Objective: To determine the impact of the COVID-19 pandemic on healthcare workers and healthcare students in higher education and to assess their clinical knowledge, media use, risk perception, perception of governmental measures, and adherence to preventive guidelines to provide policymakers with field-based evidence.

Methods: This cross-sectional quantitative survey was conducted by two-stage cluster sampling among Swiss healthcare workers, who performed patient care during the first pandemic wave, and who also pursued an education at a university of applied sciences at the same time (a Bachelor's or Master's degree in nursing or an executive degree in healthcare). 75 individuals participated between 5th May and 1st June 2020. Their data was analyzed by bivariate hypothesis testing and multiple logistic regression.

Results: Considerable levels of task-related and emotional stress were prevalent, accompanied by a large proportion of respondents who did not have sufficient protective materials or necessary decisions in place to effectively protect themselves or others from infection with COVID-19. Knowledge was considerably limited, especially regarding the efficacy of standard hygiene as a preventive measure. The preparation of the government and the healthcare sector was perceived as insufficient.

Conclusions: Comprehensive management of infodemic challenges and foresighted development of education, human resources, clinical processes, and protective materials are highly recommended.
\end{abstract}

Key Words: COVID-19, Healthcare workers, Clinical knowledge, Infodemics, Risk perception, Prevention

\section{INTRODUCTION}

\subsection{Background}

The coronavirus (COVID-19) pandemic has been severely challenging many health systems globally. As of 21 st January 2021, 95.613 million cases and 2.006 million deaths have been reported worldwide due to the disease that had its onset in late 2019. ${ }^{[1]}$ Located in Central Europe, also the Swiss population has been strongly affected, as 502438 cases have been reported to date and 8,191 people have lost their lives. ${ }^{[1]}$

In Switzerland, like in many other countries, the COVID-19 pandemic has had the potential to at its peak overload the intensive care units (ICU), despite a highly developed healthcare sector, particularly in inpatient acute care. ${ }^{[2]}$ The case of northern Italy has served as an alarming example of what an overloaded system can result in. It has shown that be-

\footnotetext{
*Correspondence: Marco Riguzzi; Email: marco.riguzzi@careum-hochschule.ch; Address: Careum Research, Careum School of Health, Zürich, Switzerland.
} 
yond infrastructural shortcomings, the human capabilities of healthcare workers (doctors, nurses, etc.) and their physical and mental well-being are key. The International Council of Nurses has reported in detail on the exhaustion of nurses in Italy, a high rate of infection among them, and infected healthcare staff needing to be isolated for 14 days, thereby creating gaps in the workforce at a most vulnerable time. ${ }^{[3]}$ For Switzerland, scientists have been warning about a high risk of infection of healthcare staff, specifically due to a lack of personal protective equipment, ${ }^{[4]}$ and about healthcare workers being a particularly challenged group during this pandemic. ${ }^{[5]}$ It is, therefore, crucial to understand these challenges imposed on healthcare workers and their protection both from a systemic and a personal perspective.

The global and local media has covered the COVID-19 pandemic extensively, particularly during its first sequence. This phenomenon has been described by the concept of infodemics, meaning that an excessive amount of information about a problem spreads rapidly despite a lack of research data. ${ }^{[6]}$ Therefore, healthcare staff able to separate facts from false information is essential to coping with the pandemic. Furthermore, healthcare workers have an important role in transmitting correct information on the disease and on preventive measures to patients, family caregivers, and the general public.

\subsection{Aims}

For healthcare institutions and policymakers to make informed decisions and enact effective programs/policies, firsthand quantitative data is essential. This survey focuses on healthcare workers in Switzerland, who were directly attending to patients during the pandemic, and who were also part-time students at a university at the time. It provides insight on a set of key factors: (1) Their factual knowledge about COVID-19, (2) the types of media they used to stay informed, (3) their risk perception, (4) their degree of concern, (5) how the outbreak affected them at work, (6) their perception of the preparedness and the reactions by the government and the healthcare system, and (7) their adherence and attitude regarding specific preventive guidelines.

\subsection{Literature on knowledge, risk perception, and emo- tional distress}

To the authors' knowledge, no quantitative study has been published in the scientific literature to date that focuses on the clinical knowledge of healthcare workers/students on COVID-19 in a highly developed healthcare system. Our study fills in this gap. While a few studies have provided evidence of the knowledge on COVID-19 for Germany, ${ }^{[7]}$ Iran, ${ }^{[8]}$ and Egypt and Nigeria, ${ }^{[9]}$ they did not focus on health- care workers, but on the general public instead. These and other studies ${ }^{[10]}$ have also analyzed risk perception regarding COVID-19, as well as attitudes and emotional concern. However, also in this regard, they have done so mostly regarding the general population, such that data on healthcare workers (or students) has remained scarce. Nevertheless, a few notable exceptions to this have been provided as follows. Puci et al. ${ }^{[11]}$ provided evidence of high perceived risk of getting infected with COVID-19 among Italian healthcare workers, as well as of sleep disturbances (64\%) and a high demand for psychological support (84\%). Spiller et al. ${ }^{[12]}$ assessed anxiety and depression within a sample of Swiss healthcare workers, however found no substantial effects caused by COVID-19. Aebischer et al. ${ }^{[13]}$ found increased levels of emotional distress among medical students who were involved in the COVID-19 response. Dratva et al. ${ }^{[14]}$ analyzed the effect of preventive measures against COVID-19 on anxiety in Swiss university students, $25 \%$ of whom were students in health professions. However, no results specific to those students in health professions were provided. Wahed et al. ${ }^{[15]}$ in their study from Egypt reported that in a sample of healthcare workers, a proportion of $83 \%$ experienced the fear of contracting COVID-19, naming insufficient protective materials, being afraid to infect family members, as well as social stigma as the most important reasons. Girma et al. ${ }^{[16]}$ measured risk perception by healthcare workers in Ethiopia using a 5-point Likert scale. They concluded an increased degree of perceived vulnerability due to COVID-19 compared to other common infectious diseases. Abolfotouh et al. ${ }^{[17]}$ analyzed risk perception and concern of healthcare workers in Saudi Arabia, identifying lower education and young age as driving factors. In addition, two projects are currently in preprint: One of them concludes a supportive employer to be a stronger (negative) predictor of burnout and anxiety than exposure to COVID-19 patients, according to a sample of Swiss nurses and residents. ${ }^{[18]}$ The other project points out risk factors and certain risk groups concerning mental distress among employees of public hospitals in Switzerland and Italy ${ }^{[19]}$ Despite these and other contributions on risk perception and emotional distress regarding COVID-19, there is still little quantitative data specific to healthcare workers from Switzerland. Also, the highlighted studies pertain to specific circumstances given during a respective survey. The policies in place at the time, as well as the situation regarding protective material, were therefore considerably heterogeneous. We chose a different route by asking the respondents to evaluate the threat caused by COVID-19 in a more general form, irrespectively of the specific preventive measures/policies in place at a particular point in time (see subsection "2.3 data collection" for explanation), thereby al- 
lowing for a higher degree of comparability across different settings and health threats.

\subsection{Literature on work-related consequences, policy, and adherence to guidelines}

The impact of the COVID-19 pandemic on healthcare systems, as well as the reactions by healthcare institutions and governments, have been the subject of several recent studies from different countries. These studies have focused on topics such as the initial preparation and first reaction after the outbreak, ${ }^{[20]}$ strategies of contact tracing and isolation as the pandemic evolved, ${ }^{[21]}$ protective equipment for healthcare staff, ${ }^{[22]}$ work risks in the healthcare sector, ${ }^{[23]}$ lockdown measures, ${ }^{[24]}$ governmental policy effectiveness, ${ }^{[25,26]}$ and key lessons to be learned. ${ }^{[27]}$ Nevertheless, our study closes a gap by focusing specifically on healthcare workers/students and their experiences, assessment, and knowledge as a source of quantitative empirical information, while such data is still scarce: Spiller et al. ${ }^{[12]}$ found that hours worked by Swiss healthcare workers had increased during the height of the first pandemic wave but afterward did not fully converge back to the levels before the pandemic. Uccella et al. ${ }^{[19]}$ found a similar result specific to intensive care in Italy and Switzerland. Pertaining to policy measures, Wolf et al. ${ }^{[28]}$ analyzed the impact of "lockdown" measures on dental practices and broader economic concepts, such as unemployment, while Abolfotouh et al. ${ }^{[17]}$ focused on the approval by Saudi Arabian healthcare workers of isolation measures, travel restrictions, and curfew. Adherence to preventive guidelines by healthcare workers, such as the wearing of gloves or masks, has been studied by Girma et al. ${ }^{[16]}$ based on a survey from Ethiopia. Similarly, a study from China by Zhang et al. ${ }^{[29]}$ concluded that specific precautionary practices, as instructed by hospitals to their employees, were implemented correctly by $90 \%$ of the healthcare workers. Our study contributes by assessing the adherence to a set of precautionary guidelines by the Swiss government, which were not legally binding but rather recommendations to the general public. These guidelines concerned social distancing, hand hygiene, limited use of public transportation, and self-imposed quarantine in the case of typical COVID-19 symptoms, and therefore were also relevant to the private life of the respondents.

\section{METHOD}

\subsection{Study setting}

This cross-sectional survey-based study was conducted over a period of 27 days (May 5th until June 1st, 2020) with students of a University of Applied Sciences (UAS) in Zurich, Switzerland, which is one out of seven UAS in the country with a health science department. The UAS offers Bachelor's and Master's programs in nursing and executive degrees in

Published by Sciedu Press healthcare. Since it only provides part-time study programs to allow students to pursue their professional careers, all respondents were also working in the healthcare sector and directly attending to patients during the pandemic. According to Swiss regulations, no approval by an ethics committee was required for this study.

The survey was conducted given the following circumstances regarding the COVID-19 pandemic: By the end of February 2020, there were still relatively few cases of COVID-19 diagnosed in Switzerland (below 20 per day). Daily infections then increased rapidly to a peak of 1,465 new cases on 23 rd March. The national government enacted preventive regulations, with the most restrictive "phase one" in effect from 17th March until 26th April 2020 (a "lockdown"), followed by a less restrictive "phase two" (starting on 27th April). As a result, infections decreased to 68 daily cases by the start of the survey (5th May) and to only 6 newly reported cases on the final day of the survey (1st June). ${ }^{[1]}$ Hence, as the respondents were answering the questionnaire, the Swiss government had already eased its measures against the COVID-19 pandemic after the first wave: From 27th April, hospitals were allowed to resume all services, including nonurgent procedures, and also massage practices, hairdressers, and cosmetic studios were allowed to reopen. ${ }^{[30]}$ At that time, there was no general obligation to wear a mask in public (or in public transportation or stores) yet, but gatherings of more than five people were prohibited. ${ }^{[30]}$ From 11th May, shops, restaurants, markets, museums, and libraries were allowed to reopen, and classes of primary and lower secondary school, as well as sports trainings resumed. ${ }^{[30]}$ On 13th May, the Swiss Federal Council ${ }^{[30]}$ announced border restrictions between Switzerland, Germany, Austria, and France to be gradually relaxed from 15 th June.

\subsection{Respondent characteristics}

A sample of 75 healthcare workers/students from Switzerland participated in this survey. $48 \%$ of them directly worked with COVID-19-infected patients, and for $36 \%$ it was undetermined yet whether they would do so at a later time. $84 \%$ were female, and age ranged between 23 and 59 years with a median of 38 (see Table 1).

\subsection{Data collection}

The data were collected by two-stage cluster sampling, with all UAS students within the cluster being invited for participation. A standardized online questionnaire was sent to the 324 students of the respective UAS on 5th May 2020 via e-mail. All messages were delivered, 69\% were opened and 57\% were read, as controlled by Mailworx software. A reminder was sent on 20th May. 86 students (27\%) participated, 79 
(24\%) completed the questionnaire to the final question, and $75(23 \%)$ regularly worked in direct contact with patients and therefore belonged to the population of main interest. The median completion time per respondent was 13.1 minutes.

Table 1. Demographic and work-related characteristics of healthcare workers/students in a survey about COVID-19 in Switzerland, May 5th until June 1st, $2020(\mathrm{n}=75)$

\begin{tabular}{|c|c|}
\hline \multicolumn{2}{|l|}{ Characteristics } \\
\hline \multicolumn{2}{|l|}{ Works with COVID-19 patients ${ }^{*} \%(n)$} \\
\hline Yes & $48.0(36)$ \\
\hline No & $16.0(12)$ \\
\hline Still undetermined at the time & $36.0(27)$ \\
\hline \multicolumn{2}{|l|}{ Health sector (multiple sectors allowed) \% (n) } \\
\hline Acute care (incl. psychiatric acute care) & $50.7(38)$ \\
\hline Nursing homes & $17.3(13)$ \\
\hline Home care & $21.3(16)$ \\
\hline Outpatient clinic & $8.0(6)$ \\
\hline Education & $6.7(5)$ \\
\hline Other & $6.7(5)$ \\
\hline No answer & $1.3(1)$ \\
\hline \multicolumn{2}{|l|}{ Age (years) } \\
\hline Mean \pm SD & $38.1 \pm 8.8$ \\
\hline Median (min-max) & $38(23-59)$ \\
\hline$<30 \%(\mathrm{n})$ & $21.3(16)$ \\
\hline$[30,40)$ & $36.0(27)$ \\
\hline$[40,50)$ & $33.3(25)$ \\
\hline$\geq 50$ & $9.3(7)$ \\
\hline \multicolumn{2}{|l|}{ Gender, children \% (n) } \\
\hline Female & $84.0(63)$ \\
\hline Has children (of any age) & $33.3(21)$ \\
\hline Has children (minors only) & $25.4(16)$ \\
\hline Male & $16.0(12)$ \\
\hline Has children (of any age) & $58.3(7)$ \\
\hline Has children (minors only) & $58.3(7)$ \\
\hline \multicolumn{2}{|l|}{ Lives by her/himself \% (n) } \\
\hline Yes & $22.7(17)$ \\
\hline No & $77.3(58)$ \\
\hline \multicolumn{2}{|l|}{ Country $^{\dagger} \%(n)$} \\
\hline Switzerland & $77.3(58)$ \\
\hline Germany & $12.0(9)$ \\
\hline Other & $10.7(8)$ \\
\hline
\end{tabular}

"within 6 months following the survey; "in which most of the healthcare worker's/student's education has been passed.

The questions were posed in multiple answer or multiple choice form. Therein, the answer option "other" was frequently included, which, if selected, led to a request for specification via text input. The details and wording of the specific questions are provided in Tables 2 through 6 . Further questions, which are not detailed in the tables, were posed as follows. Regarding risk perception: The questions "do you think you would contract COVID-19 due to an infection at work if you took no other preventive measures than usual ("business as usual")?" and "do you think you would contract COVID-19 due to an infection in private life if you took no other preventive measures than usual ("business as usual")?" were asked each with answer options given on a 6-point Likert scale labeled "certainly not", "very unlikely", "rather unlikely", "rather likely", "very likely", and "certainly". For the question represented by items D1 through D5 in Table 5 , as presented in subsection "3.3 risk perception", the respondents were presented with the hypothetical scenario in which "no extraordinary measures were undertaken in Switzerland other than the usual measures against influenza (i.e. no prohibition of social gatherings/events, no lockdown, no extraordinary measures in hospitals)". This implied a general evaluation of the risk of COVID-19 independent of specific preventive measures and policies in place at the time. The question was then repeated with answer options given on a discrete numeric rating scale ranging from " $0=$ no threat at all" to " $10=$ very serious threat" (with only these extremes having an additional label). Regarding the degree of concern: The question "how worried do you feel because of the possibility of [the respective scenario]?" was asked for the three scenarios of "getting COVID-19 yourself", "family/friends getting COVID-19", and "many deaths among elderly/sick people", with answer options given on a 4-point Likert scale labeled "not worried at all", "a little worried", "worried", and "very worried". Regarding the reaction by the government: The question "the measures implemented by the government between 17th March and 26th April ("lockdown") were..." was posed with the multiple-choice options "... exaggerated", "...adequate", and "... not strict enough/too late/too short in duration", and for the question "which of the following claims applies to the gradual steps of relaxation of these measures, which are in place since 27th April and which are planned for the future?" the multiple-choice options "the measures should have been relaxed earlier/more strongly", "the relaxation plan is adequate", and "the measures should have been relaxed later/less strongly" were given. The entire questionnaire was organized into five parts: (1) knowledge ("right"/"wrong"/"don't know") and risk perception (4-point Likert scales, 11-point discrete numeric rating scales with labeled extremes), (2) media use ("yes"/"no", 6-point Liker scales, free text for specification), (3) concern (6-point and 4point Likert scales) and effects on work situation ("yes"/"no", free text for specification), (4) precautionary measures and reaction ("yes"/"no", 6-point and 3-point Likert scales, free text for specification), and (5) demographics. 


\subsection{Data analysis}

Confidence intervals of proportions (CI) were computed by Wilson's method. Equality of proportions was tested by Fisher's exact test ( $2 \times 2$ case) and Wilcoxon's matched-pairs signed-rank test ( $>2$-level ordinal variables). Rank correlation was assessed by Spearman's coefficient. Logistic regression modeled the effects of multiple predictors on a binary outcome. Therein, step-wise factor elimination optimized Bayes' information criterion (BIC), and the results were computed as average marginal effects (AME) denoted in percentage-point differences of the probability of a positive outcome. In addition, AME were compared with raw proportions. Hypothesis tests and confidence intervals (CI) referred to a type one error probability $(p)$ of $5 \%$, unless indicated otherwise. The answers to the questions on clinical knowledge about COVID-19 (see Table 2) were taken from the following sources: $\mathrm{K} 1,{ }^{[31]} \mathrm{K} 2,{ }^{[32]} \mathrm{K} 3,{ }^{[33,34]} \mathrm{K} 4,{ }^{[35,36]} \mathrm{K} 5,{ }^{[37]}$ $\mathrm{K} 6,{ }^{[38]} \mathrm{K} 7,{ }^{[39]}$ and $\mathrm{K} 8{ }^{[40]}$

\section{RESUlts}

\subsection{Knowledge about COVID-19}

Knowledge about COVID-19 was highest concerning the absence of an effective vaccine (as of June/July 2020) (K8, $\mathrm{K} 2$ ), asymptomatic cases (K1), and transmission without physical contact (K3), with above $90 \%$ of the respondents answering correctly (see Table 2). Knowledge was significantly lower regarding infectiousness (K5), incubation time (K6), and the rate of life-threatening disease progression (K7), as compared between COVID-19 and influenza, with at least $68 \%$ correct answers per category $(p<.01$ for the pair-wise comparison of each of these three items with K1-3 and K8, Fisher's exact test). Only $51 \%$ of the respondents correctly answered that frequent washing of hands and sneezing into tissues did not virtually exclude the possibility of an infection (K4), which is a significantly smaller proportion than in any other category ( $p<.05$ vs. $\mathrm{K} 5$ and $\mathrm{K} 7, p<.01$ vs. K6, $p<.001$ vs. K1-K3 and K8, Fisher's exact test). Knowledge in the latter regard (K4) was significantly lower among respondents who lived by themselves $(\mathrm{AME}=-40$ percentage points, $p<.001$, raw proportions $24 \%$ vs. $59 \%$ ). Furthermore, males had less knowledge about infectiousness $(\mathrm{K} 5, \mathrm{AME}=-39$ percentage points, $p<.05$, raw proportions $42 \%$ vs. $76 \%)$.

When asked whether they needed more information on specific COVID-19-related topics than they had at the time, almost half of the respondents (49\%, I7) named treatment, which is a significantly larger proportion than in any other category ( $p<.05$ vs. I1 and I6, $p<.01$ vs. I 2 and I5, $p$ $<.001$ vs. I3 and I4, Fisher's exact test, see Table 3). A third named severe disease progression $(33 \%, \mathrm{I} 6)$ and transmission of the virus between people $(32 \%, \mathrm{I} 1)$, respectively. About a quarter named incubation time $(28 \%, \mathrm{I} 2)$, preventive measures $(23 \%, \mathrm{I} 4)$, and infectiousness $(27 \%$, I5), respectively. The smallest proportion of mentions was given for symptoms (19\%, I3). $23 \%$ (CI 15\%-33\%) of the respondents indicated they did not need any further information on these topics (I1-I7), or other topics related to COVID-19, while $12 \%$ (CI 6\%-21\%) indicated the need for further information on all of these topics. The respondents were asked to suggest any further topics themselves, which resulted in: long-term effects and rehabilitation (4 mentions), correct use and effectiveness of face masks and preventive material in general (3), immunity/immunization (2), sources of infection (2), vaccine (1), risk groups (1), mortality rate (1), representativeness of samples (1), sensitizing of the public (1), quarantine together with family members (1), and long-term measures remaining in effect in the healthcare sector after measures for the general public will have been abolished (1).

Table 2. Knowledge of healthcare workers/students about COVID-19 in a survey from Switzerland, May 5th until June 1st, $2020(\mathrm{n}=75)$

\begin{tabular}{lllll}
\hline No & Item & Freq. & \multicolumn{2}{l}{ CI (Wilson) } \\
\hline Correct indication provided on the following statements being true/false. & \% (n) & \% & \% \\
\hline K1 & COVID-19 leads to symptoms in every case. (False) & $94.7(71)$ & 87.1 & 97.9 \\
K2 & There currently (June/July 2020) is an effective vaccination against COVID-19. (False) & $93.3(70)$ & 85.3 & 97.1 \\
K3 & COVID-19 is transmitted between people exclusively via physical contact. (False) & $90.7(68)$ & 82.0 & 95.4 \\
K4 & If hygiene standards such as frequent washing of hands and sneezing only into tissues are & $50.7(38)$ & 39.6 & 61.7 \\
& met, an infection with COVID-19 is virtually impossible. (False) & $70.7(53)$ & 59.6 & 79.8 \\
K5 & COVID-19 has higher infectiousness than influenza. (True) & $73.3(55)$ & 62.4 & 82.0 \\
K6 & COVID-19 has a shorter incubation time than influenza. (False) & $68.0(51)$ & 56.8 & 77.5 \\
K7 & COVID-19 has a higher rate of life-threatening disease progression than influenza. (True) & $96.0(72)$ & 88.9 & 98.6 \\
K8 & Vaccines against influenza are also effective against COVID-19. (False) & & &
\end{tabular}


Table 3. Needs of healthcare workers/students for information on COVID-19, preferred sources of information, and means of communication in a survey from Switzerland, May 5th until June 1st, $2020(\mathrm{n}=75)$

\begin{tabular}{llrll}
\hline No & Item & Freq. & \multicolumn{2}{c}{ CI (Wilson) } \\
\hline \multicolumn{2}{l}{ Question: On which COVID-19-related topics do you need more detailed information than you presently have? } & \\
\hline I1 & Transmission between people. & $32.0(24)$ & 22.5 & 43.2 \\
I2 & Incubation time. & $28.0(21)$ & 19.1 & 39.0 \\
I3 & Symptoms. & $18.7(14)$ & 11.5 & 28.9 \\
I4 & Preventive measures. & $22.7(17)$ & 14.7 & 33.3 \\
I5 & Infectiousness. & $26.7(20)$ & 18.0 & 37.6 \\
I6 & Severe disease progression. & $33.3(25)$ & 23.7 & 44.6 \\
I7 & Treatment. & $49.3(37)$ & 38.3 & 60.4 \\
I8 & Other. & $18.7(14)$ & 11.5 & 28.9 \\
Question: Who should provide you with the necessary information on COVID-19? & & & \\
S1 & Employer. & & & \\
S2 & General practitioner. & $54.7(41)$ & 43.4 & 65.4 \\
S3 & Hospitals. & $16.0(12)$ & 9.4 & 25.9 \\
S4 & Government (municipal, cantonal, federal) & $21.3(16)$ & 13.6 & 31.9 \\
S5 & Journalists/publishers & $73.3(55)$ & 62.4 & 82.0 \\
S6 & Scientists/universities & $13.3(10)$ & 7.4 & 22.8 \\
S7 & Other. & $72.0(54)$ & 61.0 & 80.9 \\
Question: How do you prefer to receive the necessary information on COVID-19? & $8.0(6)$ & 3.7 & 16.4 \\
M1 & Postal delivery. & & & \\
M2 & Billboards. & $18.7(14)$ & 11.5 & 28.9 \\
M3 & Public television. & $17.3(13)$ & 10.4 & 27.4 \\
M4 & Advertisements in newspapers. & $61.3(46)$ & 50.0 & 71.5 \\
M5 & Newspaper articles. & $10.7(8)$ & 5.5 & 19.7 \\
M6 & Radio. & $48.0(36)$ & 37.1 & 59.1 \\
M7 & Leaflets. & $48.0(36)$ & 37.1 & 59.1 \\
M8 & Orally by the employer. & $5.3(4)$ & 2.1 & 12.9 \\
M9 & In writing by the employer. & $14.7(11)$ & 8.4 & 24.4 \\
M10 & Other. & $49.3(37)$ & 38.3 & 60.4 \\
\hline & & $24.0(18)$ & 15.8 & 34.8 \\
\hline
\end{tabular}

Items I1-7 (see Table 3) were compared with K1-8 (see Table 2) to assess the respondents' self-evaluation of their knowledge. Item K4, which concerns the effectiveness of frequent hand washing and sneezing into tissues, again stands out: Respondents who lacked knowledge on K4 were mostly unaware of it. Among the respondents who gave the wrong answer here, thereby overestimating effectiveness, significantly fewer indicated to be needing more information on preventive measures $(12 \%, \mathrm{I} 4)$ than among those who gave the right answer $(32 \%, p<.05$, Fisher's exact test, one-sided). The analogous applied to the claimed need for information on transmission between people (I1, $18 \%$ vs. $42 \%, p<.05$, Fisher's exact test, one-sided). This was not the case for any other category of knowledge about COVID-19 (K1-3, K5-8).
Most respondents wished for the government $(73 \%, \mathrm{~S} 4)$ or scientists/universities $(72 \%, \mathrm{~S} 6)$ to provide them with the necessary information about COVID-19 (see Table 3). More than half required information through their employer (55\%, S1). Only $13 \%$ (S5) named journalists and publishers. The most popular means by which to receive this information were public television $(61 \%, \mathrm{M} 3)$, newspaper articles $(48 \%$, M5), and radio programs (48\%, M6). Of those respondents who required information through their employer (41 respondents), most (90\%) would like to receive it in writing (M9) and a quarter (also) orally (27\%, M8).

\subsection{Media use}

When asked about their typical use of media to keep informed on recent news, not only related to COVID-19, the 
respondents reported to more frequently be using free daily newspaper articles without subscription (U2), radio programs (U4) and tv programs (U3), as opposed to daily newspaper articles requiring subscription (U1) and news messages automatically suggested by web browsers (U5) $(p<.01$, six levels, Wilcoxon's signed-rank test, Table 4). Or the four media types U1 through U4, a proportion of $23 \%$ (CI $15 \%$ $33 \%$ ) of the respondents used each type at least once a week, and $95 \%$ (CI 87\%-98\%) used at least one type at least once a week.

Table 4. Regular media use of healthcare workers/students in a survey from Switzerland, May 5th until June 1st, $2020(\mathrm{n}=$ 75)

\begin{tabular}{|c|c|c|c|c|c|c|c|}
\hline No & Item & $\%(n)$ & $\%(n)$ & $\%$ (n) & $\%$ (n) & $\%(n)$ & $\%(n)$ \\
\hline & & [CI \%] & [CI \%] & [CI \%] & [CI \%] & [CI \%] & [CI \%] \\
\hline \multicolumn{2}{|c|}{$\begin{array}{l}\text { Question: How often do you usually (not only } \\
\text { regarding COVID-19) use the following media to } \\
\text { keep informed on recent news? }\end{array}$} & Daily & $\begin{array}{l}\geq \text { Several } \\
\text { times a } \\
\text { week }\end{array}$ & $\begin{array}{l}\geq \text { Once a } \\
\text { week }\end{array}$ & $\begin{array}{l}\geq \text { Once a } \\
\text { month }\end{array}$ & $\begin{array}{l}\geq \text { Less than } \\
\text { once a month }\end{array}$ & Never \\
\hline U1 & $\begin{array}{l}\text { Daily newspapers requiring subscription } \\
\text { (also digital) }\end{array}$ & $\begin{array}{l}26.7(20) \\
{[18.0 ; 37.6]}\end{array}$ & $\begin{array}{l}37.3(28) \\
{[27.3 ; 48.6]}\end{array}$ & $\begin{array}{l}42.7(32) \\
{[32.1 ; 53.9]}\end{array}$ & $\begin{array}{l}49.3(37) \\
{[38.3 ; 60.4]}\end{array}$ & $\begin{array}{l}57.3(43) \\
{[46.1 ; 67.9]}\end{array}$ & $\begin{array}{l}42.7(32) \\
{[32.1 ; 53.9]}\end{array}$ \\
\hline $\mathrm{U} 2$ & $\begin{array}{l}\text { Free daily newspapers without subscription } \\
\text { (also digital) }\end{array}$ & $\begin{array}{l}38.7(29) \\
{[28.5 ; 50.0]}\end{array}$ & $\begin{array}{l}53.3(40) \\
{[42.2 ; 64.2]}\end{array}$ & $\begin{array}{l}65.3(49) \\
{[54.1 ; 75.1]}\end{array}$ & $\begin{array}{l}74.7(56) \\
{[63.8 ; 83.1]}\end{array}$ & $\begin{array}{l}93.3(70) \\
{[85.3 ; 97.1]}\end{array}$ & $\begin{array}{l}6.7(5) \\
{[2.9 ; 14.7]}\end{array}$ \\
\hline U3 & $\mathrm{TV}$ programs (also via internet) & $\begin{array}{l}26.7(20) \\
{[18.0 ; 37.6]}\end{array}$ & $\begin{array}{l}61.3(46) \\
{[50.0 ; 71.5]}\end{array}$ & $\begin{array}{l}74.7(56) \\
{[63.8 ; 83.1]}\end{array}$ & $\begin{array}{l}85.3(64) \\
{[75.6 ; 91.6]}\end{array}$ & $\begin{array}{l}93.3(70) \\
{[85.3 ; 97.1]}\end{array}$ & $\begin{array}{l}6.7(5) \\
{[2.9 ; 14.7]}\end{array}$ \\
\hline $\mathrm{U} 4$ & Radio programs (also via internet) & $\begin{array}{l}30.7(23) \\
{[21.4 ; 41.8]}\end{array}$ & $\begin{array}{l}62.7(47) \\
{[51.4 ; 72.7]}\end{array}$ & $\begin{array}{l}77.3(58) \\
{[66.7 ; 85.3]}\end{array}$ & $\begin{array}{l}81.3(61) \\
{[71.1 ; 88.5]}\end{array}$ & $\begin{array}{l}88.0(66) \\
{[78.7 ; 93.6]}\end{array}$ & $\begin{array}{l}12.0(9) \\
{[6.4 ; 21.3]}\end{array}$ \\
\hline U5 & $\begin{array}{l}\text { News automatically suggested by Google or } \\
\text { other web browsers }\end{array}$ & $\begin{array}{l}16.0(12) \\
{[9.4 ; 25.9]}\end{array}$ & $\begin{array}{l}38.7(29) \\
{[28.5 ; 50.0]}\end{array}$ & $\begin{array}{l}49.3(37) \\
{[38.3 ; 60.4]}\end{array}$ & $\begin{array}{l}54.7(41) \\
{[43.4 ; 65.4]}\end{array}$ & $\begin{array}{l}70.7(53) \\
{[59.6 ; 79.8]}\end{array}$ & $\begin{array}{l}29.3(22) \\
{[20.2 ; 40.4]}\end{array}$ \\
\hline
\end{tabular}

Note. The six answer options to the question presented in Table 4 were "daily", "several times a week", "once a week", "once a month", "less than once a month", and "never". " $\geq$ Less than once a month" encompasses all individuals who answered "less than once a month", "once a month", "once a week", "several times a week" or "daily", excluding those who answered "never". "CI" stands for Wilson's confidence interval.

\subsection{Risk perception}

Half of the respondents (52\%, CI 41\%-63\%) estimated that if they took no specific preventive measures, other than the usual ones they took irrespectively of COVID-19, they would "very likely" or "certainly" be infected with COVID-19 during work, while a quarter (24\%, CI $16 \%-35 \%)$ estimated that they would "very likely" or "certainly" be infected in private life (which is a significantly smaller proportion, $p$ $<.05$, Fisher's exact test, one-sided). The potential threat imposed by the COVID-19 pandemic, for the hypothetical case in which no preventive measures would have been taken in Switzerland other than the usual measures against common influenza, was perceived as follows (D1-5, Table 5): It was perceived as a "severe threat" to one's own life by $32 \%$ of the respondents. This was a significantly smaller proportion than concerning the life of family members $(67 \%)$, healthcare workers attending to COVID-19-infected patients (77\%), the Swiss population (76\%), or the global population $(83 \%)(p<.001$, Fisher's exact test, for each pair-wise comparison involving one's own life). When comparing the degree of threat estimated on the 11-point discrete rating scale, the majority of respondents estimated COVID-19 to be a strictly more severe threat to the global population $(72 \%$, CI $60 \%-82 \%$ ), to the Swiss population (67\%, CI 55\%-77\%), to healthcare workers attending to COVID-19 patients (71\%,
CI $59 \%-81 \%)$, and to the life of their family members $(63 \%$, CI $51 \%-74 \%$ ) than to their own life. No respondent estimated a higher threat to the Swiss population than to the global population (CI 0-5\%).

\subsection{Degree of concern}

The respondents displayed a significantly higher degree of concern about their family getting infected, as well as about elderly or sick people who might die as a result of an infection, than about themselves getting infected $(p<0.001$, Wilcoxon's signed-rank test, ordinal variables with the four levels "not at all worried", "a little worried", "worried", "very worried"). $64 \%$ felt at least "worried" regarding their family (CI 53\%-74\%), with $31 \%$ feeling "very worried" (CI 21\%$42 \%$ ). Concerning deaths among elderly and sick people, again 64\% felt at "least worried" (CI 53\%-74\%), with 24\% feeling "very worried" (CI 16\%-35\%). Only 16\% felt at least "worried" for themselves (CI 9\%-26\%), with 3\% feeling "very worried" (CI 1\%-9\%). Multiple logistic regression showed that they were significantly more likely to feel at least "worried" about family getting infected, if they (the respondents themselves) had a health condition that put them in a COVID-19-risk group (AME $=29$ percentage points, $p<.01$, raw proportions $78 \%$ vs. $62 \%$ ), and less likely if they worked for a geriatric institution (AME $=-25$ percentage points, $p<$ .05 , raw proportions $41 \%$ vs. $74 \%$ ) or had children (AME 
$=-38$ percentage points, $p<.001$, raw proportions $41 \%$ vs. $78 \%)$.

\subsection{Effects on the work situation}

Almost half of the respondents reported that due to COVID19 , they had to work more hours than usual (47\%, item W2), and that they had to perform tasks that were unusual to them (47\%, W4), respectively (see Table 5). Also, 21\% worked for a department or division at their workplace which they usually did not work for (W5). $41 \%$ felt more stressed (W1), and $29 \%$ were more frequently pressed for time (W3). $41 \%$ disagreed with the claim that in their workplace, the necessary material and structures to effectively protect the staff from an infection with COVID-19 were available (W7), and $32 \%$ disagreed with the claim that the necessary decisions in this regard were taken (W8). Every respondent indicated that their work situation had been affected by COVID-19 in some way (W1-W10, CI 95\%-100\%). Other effects described by the open-answer option "other" (W10), besides the predefined categories given by the questionnaire (W1-8), were: highlighting that protective masks were insufficiently available in addition to selecting item W7 (4 mentions), high expenditure of time for communication on COVID-19 and reading/intake of information (3 mentions). Furthermore, single mentions were given of insufficient protective material for staff members who belonged to a risk group, COVID-19 infection of patients detected late leading to protective material not having been worn in time, not all possible preventive measures being applied, stressful restrictions in a geriatric institution, saddening situations of patients not seeing their relatives for weeks, an employer breaching labor law, another employer instead strongly considering the needs of staff members, adequate preparation for and dealing with the COVID-19 pandemic, less work than usual, and home office.

Table 5. Work situation, risk perception, and preparation of the government and the healthcare sector according to healthcare workers/students in a survey about COVID-19 in Switzerland, May 5th until June 1st, 2020 (n = 75)

\begin{tabular}{|c|c|c|c|c|}
\hline \multirow[t]{2}{*}{ No } & \multirow[t]{2}{*}{ Item } & \multirow{2}{*}{$\begin{array}{l}\text { Freq. } \\
\%(n)\end{array}$} & \multicolumn{2}{|c|}{ CI (Wilson) } \\
\hline & & & $\%$ & $\%$ \\
\hline \multicolumn{5}{|c|}{ Question: How has/had COVID-19 affected your work situation? } \\
\hline W1 & I feel more stressed than usual. & $41.3(31)$ & 30.9 & 52.6 \\
\hline W2 & I have to work more than usual. & $46.7(35)$ & 35.8 & 57.8 \\
\hline W3 & I am more often pressed for time than usual. & $29.3(22)$ & 20.2 & 40.4 \\
\hline W4 & I have to do tasks that are unusual to me. & $46.7(35)$ & 35.8 & 57.8 \\
\hline W5 & I work for a department/division (at least in part) which I do not usually work for. & $21.3(16)$ & 13.6 & 31.9 \\
\hline W6 & My employer shows less consideration for my needs than usual. & $28.0(21)$ & 19.1 & 39.0 \\
\hline W7 & $\begin{array}{l}\text { The material and structures necessary to effectively protect the staff from infection } \\
\text { with COVID-19 are available. }\end{array}$ & $58.7(44)$ & 47.4 & 69.1 \\
\hline W8 & $\begin{array}{l}\text { The decisions necessary to effectively protect the staff from infection with COVID-19 } \\
\text { are taken. }\end{array}$ & $68.0(51)$ & 56.8 & 77.5 \\
\hline W10* & Other. & $24.0(18)$ & 15.8 & 34.8 \\
\hline W11 & Not at all. & $0.0(0)$ & 0.0 & 4.9 \\
\hline
\end{tabular}

Agreement with the claim: COVID-19 would be a severe threat if no extraordinary measures were undertaken, other than usual measures against influenza (i.e. no prohibition of social gatherings/events, no lockdown, no extraordinary measures in hospitals).

D1 To one's own life.

$32.0(24) \quad 22.5 \quad 43.2$

D2 To the life of family members.

$\begin{array}{lll}66.7(50) & 55.4 & 76.3\end{array}$

D3 To healthcare workers attending to COVID-19 patients.

$\begin{array}{lll}77.3(58) & 66.7 \quad 85.3\end{array}$

D4 To the Swiss population.

$76.0(57) \quad 65.2 \quad 84.2$

D5 To the global population.

$82.7(62)$

$72.6 \quad 89.6$

\begin{tabular}{|c|c|c|c|c|}
\hline \multicolumn{5}{|c|}{$\begin{array}{l}\text { Question: Which of the following claims are true? Ahead of the outbreak of COVID-19, tl } \\
\text { system were sufficiently prepared for a viral pandemic with... }\end{array}$} \\
\hline P1 & Disinfectant and protective masks. & $9.3(7)$ & 4.6 & 18.0 \\
\hline $\mathrm{P} 2$ & Personnel. & $21.3(16)$ & 13.6 & 31.9 \\
\hline P3 & Structures. & $26.7(20)$ & 18.0 & 37.6 \\
\hline P4 & Processes and contingency plans. & $28.0(21)$ & 19.1 & 39.0 \\
\hline P5 & $\begin{array}{l}\text { None of the above claims are true. In none of these four areas were the government and } \\
\text { the healthcare sector sufficiently prepared. }\end{array}$ & $53.3(40)$ & 42.2 & 64.2 \\
\hline
\end{tabular}

*Item W9 of the questionnaire was not included in this survey. 
3.6 Preparedness and reaction by the government and the healthcare system

The vast majority claimed that ahead of the outbreak of COVID-19, the government and the healthcare sector were insufficiently prepared for a viral pandemic concerning personnel $(79 \%, \mathrm{P} 2)$, structures (73\%, P3), and processes and contingency plans $(72 \%, \mathrm{P} 4)$, respectively (see Table 5 ). Nearly all respondents $(91 \%, \mathrm{P} 1)$ claimed that preparation was insufficient regarding disinfectant and protective masks. Half of the respondents concluded that in none of these four categories the government and the healthcare sector were sufficiently prepared $(53 \%$, P5). When asked for their opinion on the protective measures imposed by the Swiss government during "phase one" (17th March-26th April 2020, "lockdown"), two thirds thought that they were "appropriate" (67\% CI 56\%-77\%), while $16 \%$ (CI 10\%-26\%) found them to be "not restrictive enough/too late/too short". Roughly half found the less restrictive "phase two" (the relaxation of measures starting on 27th April) to be "appropriate" (55\%, CI 44\%-66\%), while 34\% (CI 24\%-45\%) found it to be "too early/too liberal".

\subsection{Adherence and attitude regarding preventive guide- lines}

Strict adherence (answer "always") to preventive guidelines (including work and private life) was highest regarding the following measures (see Table 6): no shaking of hands (92\%, A5), no uncovered coughing or sneezing ( $84 \%$, A6), and not leaving home with a cough or fever $(84 \%$, A7). $69 \%$ (A1) made no use of public transportation during rush hour, $64 \%$ (A2) strictly avoided gatherings of more than five people, and $49 \%$ (A4) disinfected or washed their hands with soap for 20 seconds after each physical contact except within their family. $45 \%$ (A8) strictly refrained from contact with people older than 65 years, and only $28 \%$ (A3) strictly kept a physical distance of at least two meters (the distance recommended by the Swiss government at the time) from everyone except their closest family. It needs to be kept in mind regarding the latter result that the respondents all worked with patients at the time. Each of these guidelines (A1-A8) was followed by the majority of the respondents at least "almost always" (with a CI above at least $51 \%$ ), and by at least three quarters "predominantly" (with a CI above at least 65\%). The pair-wise rank correlation among guidelines A1 through A8 was low to moderate throughout, with the highest correlation coefficient amounting to only 0.34 for the pair of keeping a physical distance (A3) and refusing handshakes (A5) ( $p$ $<.01$ for this pair). Hence, when comparing two randomly drawn individuals, one having higher adherence than the other to a certain guideline did not imply a high probability of the same being the case also regarding another guideline. "Almost always" or "always" keeping a physical distance of two meters from everyone except closest family (A3) was more frequent among respondents with children $(\mathrm{AME}=34$ percentage points, $p<.001$, raw proportions $82 \%$ vs. $51 \%$ ).

Table 6. Adherence to preventive guidelines of healthcare workers/students after the first wave of COVID-19 in a survey from Switzerland, May 5th until June 1st, $2020(\mathrm{n}=75)$

\begin{tabular}{|c|c|c|c|c|c|c|c|}
\hline No & Item & $\%(n)$ & $\%(n)$ & $\%(n)$ & $\%(n)$ & $\%(n)$ & $\%(n)$ \\
\hline & & [CI \%] & [CI \%] & [CI \%] & [CI \%] & [CI \%] & [CI \%] \\
\hline \multicolumn{2}{|r|}{ Question: How strictly do you follow these guidelines? } & Always & $\begin{array}{l}\geq \text { Almost } \\
\text { always }\end{array}$ & $\begin{array}{l}\geq \\
\text { Predominantly }\end{array}$ & $\leq$ Sometimes & $\begin{array}{l}\leq \text { Almost } \\
\text { never }\end{array}$ & Never \\
\hline A1 & Make no use of public transportation during rush hour. & $\begin{array}{l}69.3(52) \\
{[58.2 ; 78.6]}\end{array}$ & $\begin{array}{l}80.0(60) \\
{[69.6 ; 87.5]}\end{array}$ & $\begin{array}{l}88.0(66) \\
{[78.7 ; 93.6]}\end{array}$ & $\begin{array}{l}12.0(9) \\
{[6.4 ; 21.3]}\end{array}$ & $\begin{array}{l}6.7(5) \\
{[2.9 ; 14.7]}\end{array}$ & $\begin{array}{l}5.3(4) \\
{[2.1 ; 12.9]}\end{array}$ \\
\hline A2 & $\begin{array}{l}\text { Refrain from meetings (also private) involving more } \\
\text { than five people. }\end{array}$ & $\begin{array}{l}64.0(48) \\
{[52.7 ; 73.9]}\end{array}$ & $\begin{array}{l}88.0(66) \\
{[78.7 ; 93.6]}\end{array}$ & $\begin{array}{l}96.0(72) \\
{[88.9 ; 98.6]}\end{array}$ & $\begin{array}{l}4.0(3) \\
{[1.4 ; 11.1]}\end{array}$ & $\begin{array}{l}2.7(2) \\
{[0.7 ; 9.2]}\end{array}$ & $\begin{array}{l}1.3(1) \\
{[0.2 ; 7.2]}\end{array}$ \\
\hline A3 & $\begin{array}{l}\text { Keep a physical distance of at least two meters from } \\
\text { everyone except your closest family. }\end{array}$ & $\begin{array}{l}28.0(21) \\
{[19.1 ; 39.0]}\end{array}$ & $\begin{array}{l}62.7(47) \\
{[51.4 ; 72.7]}\end{array}$ & $\begin{array}{l}84.0(63) \\
{[74.1 ; 90.6]}\end{array}$ & $\begin{array}{l}16.0(12) \\
{[9.4 ; 25.9]}\end{array}$ & $\begin{array}{l}4.0(3) \\
{[1.4 ; 11.1]}\end{array}$ & $\begin{array}{l}2.7(2) \\
{[0.7 ; 9.2]}\end{array}$ \\
\hline A4 & $\begin{array}{l}\text { Disinfect or wash your hands with soap for } 20 \text { seconds } \\
\text { after each physical contact, except with family. }\end{array}$ & $\begin{array}{l}49.3(37) \\
{[38.3 ; 60.4]}\end{array}$ & $\begin{array}{l}74.7(56) \\
{[63.8 ; 83.1]}\end{array}$ & $\begin{array}{l}89.3(67) \\
{[80.3 ; 94.5]}\end{array}$ & $\begin{array}{l}10.7(8) \\
{[5.5 ; 19.7]}\end{array}$ & $\begin{array}{l}4.0(3) \\
{[1.4 ; 11.1]}\end{array}$ & $\begin{array}{l}1.3(1) \\
{[0.2 ; 7.2]}\end{array}$ \\
\hline A5 & Do not shake hands. & $\begin{array}{l}92.0(69) \\
{[83.6 ; 96.3]}\end{array}$ & $\begin{array}{l}93.3(70) \\
{[85.3 ; 97.1]}\end{array}$ & $\begin{array}{l}96.0(72) \\
{[88.9 ; 98.6]}\end{array}$ & $\begin{array}{l}4.0(3) \\
{[1.4 ; 11.1]}\end{array}$ & $\begin{array}{l}1.3(1) \\
{[0.2 ; 7.2]}\end{array}$ & $\begin{array}{l}0.0(0) \\
{[0.0 ; 4.9]}\end{array}$ \\
\hline A6 & $\begin{array}{l}\text { Cough and sneeze only into a tissue or the inside of } \\
\text { your elbow if no tissue is available. }\end{array}$ & $\begin{array}{l}84.0(63) \\
{[74.1 ; 90.6]}\end{array}$ & $\begin{array}{l}100.0(75) \\
{[95.1 ; 100.0]}\end{array}$ & $\begin{array}{l}100.0(75) \\
{[95.1 ; 100.0]}\end{array}$ & $\begin{array}{l}0.0(0) \\
{[0.0 ; 4.9]}\end{array}$ & $\begin{array}{l}0.0(0) \\
{[0 ; 4.9]}\end{array}$ & $\begin{array}{l}0.0(0) \\
{[0.0 ; 4.9]}\end{array}$ \\
\hline A7 & $\begin{array}{l}\text { In case of a cough or fever, do not leave your home and } \\
\text { contact the hotline or a physician via phone. }\end{array}$ & $\begin{array}{l}84.0(63) \\
{[74.1 ; 90.6]}\end{array}$ & $\begin{array}{l}96.0(72) \\
{[88.9 ; 98.6]}\end{array}$ & $\begin{array}{l}97.3(73) \\
{[90.8 ; 99.3]}\end{array}$ & $\begin{array}{l}2.7(2) \\
{[0.7 ; 9.2]}\end{array}$ & $\begin{array}{l}2.7(2) \\
{[0.7 ; 9.2]}\end{array}$ & $\begin{array}{l}2.7(2) \\
{[0.7 ; 9.2]}\end{array}$ \\
\hline A8 & $\begin{array}{l}\text { Refrain from contact with people older than } 65 \text { years, } \\
\text { including parents/other relatives. }\end{array}$ & $\begin{array}{l}45.3(34) \\
{[34.6 ; 56.6]}\end{array}$ & $\begin{array}{l}62.7(47) \\
{[51.4 ; 72.7]}\end{array}$ & $\begin{array}{l}76.0(57) \\
{[65.2 ; 84.2]}\end{array}$ & $\begin{array}{l}24.0(18) \\
{[15.8 ; 34.8]}\end{array}$ & $\begin{array}{l}17.3(13) \\
{[10.4 ; 27.4]}\end{array}$ & $\begin{array}{l}12.0(9) \\
{[6.4 ; 21.3]}\end{array}$ \\
\hline
\end{tabular}




\section{Discussion}

\subsection{Key findings}

The results of this survey provide insight into the knowledge, attitude, and practice of Swiss healthcare students in higher education who studied part-time and also provided clinical care to patients during the first wave of the COVID19 pandemic. The main aim was to identify the impact of the first wave on their work situation and how universities could respond to the infodemic challenge.

The students reported a considerable level of individual stress, while having to conduct unusual tasks for longer working hours and being concerned about COVID-19 spreading to larger populations (healthcare workers, Swiss and global population) and potentially threatening the life of their family members. This is in line with Pawar, ${ }^{[41]}$ who highlights that the pandemic has led to stress, fear, and existential anxiety among healthcare workers. Furthermore, healthcare workers being more concerned about others than about themselves (family members, elderly/sick people, colleagues) reflects the stereotype of them acting as "heroes" during the pandemic, a label which has repeatedly been assigned to them by patients and the media. ${ }^{[42]}$ As Cox mentions (2020), ${ }^{[42]}$ this label however has its downsides, particularly if it contributes to healthcare workers neglecting their own needs and working even more excessively. As discussed by Spiller et al., ${ }^{[12]}$ working hours have been sluggish to converge back to pre-pandemic volumes. However, long-term excessive labor of healthcare staff had already been a challenge before the pandemic ${ }^{[43,44]}$ and may intensify even more as a result of it. In the present survey, these stressors were accompanied by a large number of respondents who did not have sufficient protective material or necessary decisions in place to effectively protect them or other staff from a COVID-19 infection. The vast majority of respondents claimed insufficient preparation of the government and the healthcare sector to a viral pandemic in multiple respects, particularly a lack of disinfectant and protective masks, insufficient staffing, inadequate structures, or missing processes and contingency plans.

More clinical information on COVID-19 was desired by the responding students on several topics, most frequently on treatment, disease progression, and transmission. This is a typical request when new infectious diseases emerge and insights at the beginning of the pandemic concentrate on a few clinical sites before new information is disseminated to other healthcare facilities. ${ }^{[45]}$ There was a knowledge gap on the efficacy of standard hygiene as a preventive measure against COVID-19 and, to a lesser extent, on disease progression, infectiousness, and incubation time compared to common influenza. Only half of the respondents were aware that regular washing of hands and sneezing into tissues does not virtually exclude transmission of COVID-19 from one person to another. Also, the vast majority of those who did not provide the correct answer here believed that they did not need any further information on the topics of preventive measures and transmission. The divide of strenuous requirements at work and a lack of informational and tangible support in the context of COVID-19 can lead to frustration and eventually to burnout among healthcare staff. ${ }^{[18]}$ In such situations, employees in healthcare facilities might at best experience top nursing leadership during the crisis or later during a reflective inquiry of the crisis period. ${ }^{[46]}$

Experiencing such a crisis as a student who aims to develop critical thinking skills, and who has to make clinical decisions upon reliable and evidence-based information, is also a source of learning in action. Prior epidemiological crises, such as AIDS, showed that nursing students were able to shape their attitude towards AIDS patients, and to learn how to fulfill their tasks even when the government was not always reporting accurate information. ${ }^{[47]}$ Students from higher education, particularly at the university level, have to be able to handle contradictory and quickly changing information according to the Dublin Descriptors. ${ }^{[48]}$ At the intersection of studying at a university and providing clinical care, it is essential to foster the students' competencies to analyze the pandemic situation despite insufficiently available information from the employer or the government. Here, bundled and accurate information from trusted sources is particularly important, such as e.g. a newly published Cochrane Review addressing healthcare workers' adherence to prevention and control guidelines for infectious diseases. ${ }^{[49]}$

\subsection{Limitations}

Participation was not mandatory within the cluster invited to participate. Randomness, even though it cannot be excluded, was therefore not ascertained. Furthermore, although the seven Swiss UAS with health departments follow similar schemes and their geographical regions overlap, homogeneity across clusters was an unprovable assumption.

The use of masks in public, e.g. in public transportation, was not compulsory in Switzerland before July 2020, which was a month after this survey had already ended. Thus, the results might not reflect the safety-related knowledge and practice in place later in the pandemic.

\section{Conclusion}

Leadership in higher education is pivotal to supporting students when they are challenged with unprecedented amounts of information. ${ }^{[50]}$ In such critical times of infodemics, timely information management and health literacy are re- 
quired, particularly when false or incomplete information may spread among students. ${ }^{[6]}$ Healthcare educators can utilize the generation $\mathrm{Z}$ students' skills and preferences for online teaching methods. At the same time, they can increase their competencies to identify reliable and up-to-date information. ${ }^{[51]}$

Close surveillance by regular testing for viral status, as well as the provision of sufficient personal protective equipment, are essential to keep the healthcare workforce safe and able to provide their services. ${ }^{[5]}$ Moreover, healthcare workers are not only threatened by infection, but also by long working hours and other sources of stress. The emotional distress imposed on healthcare workers by the pandemic should not be neglected. There already is empirical evidence of the negative effects of the pandemic on the mental well-being of healthcare workers. ${ }^{[11,15,17]}$ While healthcare workers may be lauded for treating their personal needs as a second priority, ${ }^{[42]}$ them doing so may become increasingly consequential in the long term of the pandemic. Preventing a depletion of their mental health is important, both for the sake of the healthcare workers themselves, as well as for healthcare systems to maintain sufficient provision of healthcare services over an extended period. ${ }^{[43,44]}$ A lesson to be learned for future waves of the COVID-19 pandemic, as well as for any other pathogen that may potentially spread in the future, is that how healthcare workers have been affected varies over fields, institutions, individuals, as well as over the course of the pandemic. Therefore, solutions should be specific and remain adaptable.

Finally, the challenges imposed by the pandemic can also serve as an opportunity. Experiencing a pandemic in the midst of studying and working with patients, students may achieve competencies and identity with their profession that otherwise were not possible to this degree - a phenomenon which was observed among nursing students during a SARS outbreak in Hongkong. ${ }^{[52]}$ Opportunities for learning are particularly evident for the dos and don'ts in information management, planning for personal protective equipment, priorities in leadership when managing an epidemiological crisis, as well as healthcare policy.

\section{FUNDING}

This project was funded by the Careum School of Health which is part of the Kalaidos University of Applied Sciences in Zürich, Switzerland.

\section{ACKNOWLEDGEMENTS}

The authors thank Jacqueline Martin, Ursina Baumgartner, Milena Svec-Götschi, Marianne Frech, Michael Gysi, Qëndresa Koxha-Gashi, and the healthcare workers who took the time to participate and provide their experience and honest opinion.

\section{CONFlicts of InTEREST Disclosure}

Marco Riguzzi and Iren Bischofberger teach at the Kalaidos University of Applied Sciences in Zürich, the UAS at which the respondents of the survey were studying. However, no explicit or implicit communication of any form was held with the respondents or any other students of the Kalaidos University of Applied Sciences regarding this survey, except for the standardized invitation via e-mail (identical up to the receiver's name) described in the subsection " 2.3 data collection". A separate survey on the topic of COVID-19 was conducted among the students of Careum Weiterbildung in Aarau aroung the same time, an institution that offers education of different scope at a different level than the Kalaidos University of Applied Sciences in Zürich.

\section{REFERENCES}

[1] World Health Organization [WHO]. Coronavirus disease (COVID19). Weekly Epidemiolocal Update. January 22, 2021. Available from: https://covid19. who.int/

[2] Borasio GD, Gamondi C, Obrist M, et al. COVID-19: decision making and palliative care. Swiss Medical Weekly. 2020. https: //doi.org/10.4414/smw.2020.20233

[3] International Council of Nurses. Press Information. High proportion of healthcare workers with COVID-19 in Italy is a stark warning to the world: protecting nurses and their colleagues must be the number one priority. 2020. Available from: https://www.icn.ch/sites/default/files/inl ine-files/PR_09_COVID-19\%20-\%20Italy.pdf

[4] Canova V, Lederer-Schläpfer H, Piso-Rein J, et al. Transmission risk of SARS-CoV-2 to healthcare workers - observational results of a primary care hospital contact tracing. Swiss Medical Weekly. 2020. PMid:32333603 https://doi .org/10.4414/smw . 2020. 20257

[5] Swiss National COVID-19 Science Task Force. Policy Brief: Protecting physical and mental health of healthcare workers. 2020. Available from: https://sciencetaskforce.ch/en/policy-bri ef/elementor-6662/

[6] Zarocostas J. How to fight an infodemic. The Lancet. 2020. https : //doi.org/10.1016/S0140-6736(20) 30461-X

[7] Führer A, Frese T, Karch A, et al. COVID-19: Knowledge, risk perception and strategies for handling the pandemic. Evidence in Health Care. 2020; 153: 32-38. PMid:32601024 https://doi.org/10.1 016/j.zefq. 2020.06.002

[8] Honarvar B, Lankarani KB, Kharmandar A, et al. Knowledge, attitudes, risk perceptions, and practices of adults towards COVID19: a population and field-based study from Iran. International 
Journal of Public Health. 2020; 65: 731-739. PMid:32583009 https ://doi.org/10.1007/s00038-020-01406-2

[9] Hager E, Odetokun A, Bolarinwa O, et al. Knowledge, attitude, and perceptions towards the 2019 Coronavirus Pandemic: A binational survey in Africa. Plos One. 2020. PMid:32726340 https: //doi.org/10.1371/journal.pone.0236918

[10] Zegarra-Valdivia JA, Chino-Vilca BN, Ames-Guerrero R. Knowledge, perception and attitudes in Regard to COVID-19 Pandemic in Peruvian Population. PsyArXiv preprints. 2020. https ://doi.or g/10.31234/osf.io/kr9ya

[11] Puci MV, Nosari G, Loi F, et al. Risk perception and worries among health care workers in the covid-19 pandemic: findings from an Italian survey. Healthcare. 2020; 8: 535. PMid:33287260 https://doi.org/10.3390/healthcare8040535

[12] Spiller TR, Méan M, Ernst J, et al. Development of health care workers' mental health during the SARS-CoV-2 pandemic in Switzerland: two cross-sectional studies. Psychological Medicine. 2020; 13: 1-4. PMid:32787976 https ://doi.org/10.1017/S0033291720003 128

[13] Aebischer O, Weilenmann S, Gachoud D, et al. Physical and psychological health of medical students involved in the COVID-19 response in Switzerland. Swiss Medical Weekly. 2020. PMid:33306812 https://doi.org/10.4414/smw. 2020.20418

[14] Dratva J, Zysset A, Schlatter N, et al. Swiss University Students' Risk Perception and General Anxiety during the COVID-19 Pandemic. International Journal of Environmental Research and Public Health. 2020; 17: 7433. PMid:33066008 https://doi.org/10.3390/ij erph17207433

[15] Wahed WYA, Hefzy EM, Ahmed MI, et al. Assessment of knowledge, attitudes, and perception of health care workers regarding COVID-19, a cross-sectional study from Egypt. Journal of Community Health. 2020; 45: 1242-1251. PMid:32638199 https: //doi.org/10.1007/s10900-020-00882-0

[16] Girma S, Agenagnew L, Beressa G, et al. Risk perception and precautionary health behavior toward COVID-19 among health professionals working in selected public university hospitals in Ethiopia Plos One. 2020. PMid:33119644 https://doi .org/10.1371/jo urnal pone. 0241101

[17] Abolfotouh MA, Almutairi AF, BaniMustafa AA, et al. Perception and attitude of healthcare workers in Saudi Arabia with regard to Covid-19 pandemic and potential associated predictors. BMC Infectious Diseases. 2020; 20: 719. PMid:32993538 https : //doi.org/10.1186/s12879-020-05443-3

[18] Weilenmann S, Ernst J, Petry H, et al. Health Care Workers Mental Health During the First Weeks of the SARS-CoV-2 Pandemic in Switzerland: A Cross-Sectional Study. MedRxiv (Preprint). 2020 https://doi.org/10.1101/2020.05.04.20088625

[19] Uccella L, Majno-Hurst P, Uccella S, et al. Psychological Impact of a Pandemic Widespread in Healthcare Workers: The Italian and Swiss Perspective Early After of CoVid-19 Outbreak. Europe PMC. 2020.

[20] Barro K, Malone A, Mokede A, et al. Management of the COVID-19 epidemic by public health establishments - Analysis by the Federation Hospitaliere de France. Journal of Visceral Surgery. 2020; 157: 519 523. PMid:32417194 https://doi.org/10.1016/j.jviscsur g. 2020.04.011

[21] Salathé M, Althaus CL, Neher R, et al. COVID-19 epidemic in Switzerland: on the importance of testing, contact tracing and isolation. Swiss Medical Weekly. 2020; 150: 20225. PMid:32191813 https://doi.org/10.4414/smw. 2020.20225

[22] Park SH. Personal Protective Equipment for Healthcare Workers during the COVID-19 Pandemic. Infection \& Chemotherapy. 2020;
52(2): 165-182. PMid:32618146 https://doi.org/10.3947/ic .2020 .52 .2 .165

[23] Ali S, Noreen S, Faroog I, et al. Risk Assessment of Healthcare Workers at the Frontline against the COVID-19. Pakistan Journal of Medical Sciences. 2020. https : //doi .org/10.12669/pjms . 36 .COVID19-S4.2790

[24] Faber M, Ghisletta A, Schmidheiny KA. A lockdown index to assess the economic impact of the coronavirus. Swiss Journal of Economics and Statistics. 2020; 156: 11. PMid:32874959 https : //doi.org/10.1186/s41937-020-00056-8

[25] Dergiades T, Milas C, Mossialos E, et al. Effectiveness of Governmental Policies in Response to the COVID-19 Outbreak. 2020. http://dx.doi.org/10.2139/ssrn. 3602004

[26] Desson Z, Lamberth L, Peters JW, et al. Europe's COVID-19 outliers: German, Austrian and Swiss policy responses during the early stages of the 2020 pandemic. Health Policy and Technology. 2020; 9(4): 405-418. PMid:33520639 https://doi.org/10.1016/j . hlpt. 2020.09.003

[27] Han E, Tan MMJ, Turk E, et al. Lessons learned from easing COVID-19 restrictions: an analysis of countries and regions in Asia Pacific and Europe. The Lancet. 2020; 396(10261):, 1525-1534. https : //doi .org/10.1016/S0140-6736(20)32007-9

[28] Wolf TG, Zeyer O, Campus G. COVID-19 in Switzerland and Liechtenstein: A Cross-Sectional survey among Dentists' awareness, protective measures and economic effects. International Journal of Environmental Research and Public Health. 2020; 17(23): 9051. PMid:33291659 https://doi.org/10.3390/ijerph17239051

[29] Zhang M, Zhou M, Tang F, et al. Knowledge, attitude, and practice regarding COVID-19 among healthcare workers in Henan, China. Journal of Hospital Infection. 2020; 105(2): 183-187. PMid:32278701 https://doi.org/10.1016/j.jhin.2020.04.012

[30] Swiss Federal Council. In Press releases by the Federal Council. 2020. Available from: https://www.admin.ch/gov/en/start/ documentation/media-releases/media-releases-feder al-council.html?dyn_startDate=01.03.2020

[31] Day M. Covid-19: four fifth of cases are asymptomatic, China figures indicate. British Medical Journal. 2020; 365: 1375. PMid:32241884 https ://doi.org/10.1136/bmj.m1375

[32] Mullard A. COVID-19 vaccine development pipeline gears up. The Lancet. 2020; 3959(10239): 1751-1752. https ://doi .org/10.1 016/S0140-6736(20)31252-6

[33] Morawska L, Cao J. Airborne transmission of SARS-CoV-2: The world should face the reality. Environment International. 2020. PMid:32294574 https://doi.org/10.1016/j.envint.2020. 105730

[34] World Health Organization [WHO]. Coronavirus (COVID19) Update No.20. How it spreads. 2020. Available from: https : //www. who.int/docs/default-source/coronaviru se/risk-comms-updates/update-20-epi-win-covid-19. pdf?sfvrsn=5e0b2d74

[35] World Health Organization [WHO]. Advice on the use of masks the community, during home care and in health care settings in the context of the novel coronavirus (2019-nCoV) outbreak? Interim guidance 29 January 2020. 2020. Available from: https://www.who.int/docs/default-source/docume nts/advice-on-the-use-of-masks-2019-ncov.pdf

[36] Kaur S, Bherwani H, Gulia S, et al. Understanding COVID-19 transmission, health impacts and mitigation: timely social distancing is the key. Environment, Development and Sustainability. 2020. PMid:32837280 https : //doi.org/10.1007/s10668-020-008 $84-\mathrm{x}$ 
[37] Moore A, Lipsitch M, Barry JM, et al. COVID-19: The CIDRAP Viewpoint. Part 1: The Future of the COVID-19 Pandemic: Lessons Learned from Pandemic Influenza. 2020. Available from: https ://www.cidrap.umn.edu/sites/default/files/pub lic/downloads/cidrap-covid19-viewpoint-part1_0.pdf

[38] Centers for Disease Control and Prevention [CDC]. Similarities and Differences between Flu and COVID-19. 2020. Available from: ht tps://www.cdc.gov/flu/symptoms/flu-vs-covid19.htm

[39] Petersen E, Koopmans E, Go U, et al. Comparing SARS-CoV-2 with SARS-CoV and influenza pandemics. The Lancet Infectious Diseases. 2020; 20(9): 238-244. https ://doi .org/10.1016/S147 3-3099 (20) 30484-9

[40] World Health Organization [WHO]. Q\&A: Influenza and COVID19-similarities and differences. 2020. Available from: https: //www.who.int/westernpacific/news/q-a-detail/q-a-s imilarities-and-differences-covid-19-and-influenza

[41] Pawar M. The global impact of and responses to the COVID-19 pandemic. The International Journal of Community and Social Development. 2020; 2: 111-120. https ://doi .org/10.1177/2516 602620938542

[42] Cox CL. Healthcare Heroes": problems with media focus on heroism from healthcare workers during the COVID-19 pandemic. Journal of Medical Ethics. 2020; 46: 510-513. PMid:32546658 https : //doi.org/10.1136/medethics-2020-106398

[43] Caruso CC. Possible broad impacts of long work hours. Industrial Health. 2006; 44: 531-536. PMid:17085913 https : //doi .org/10 .2486/indhealth. 44.531

[44] Griffiths P, Dall 'Ora C, Simon M, et al. Nurses' shift length and overtime working in 12 European countries: the association with perceived quality of care and patient safety. Medical Care. 2014; 52: 975-981. PMid:25226543 https://doi.org/10.1097/MLR. 0000000000000233

[45] Affonso DD, Andrews GJ, Jeffs L. The urban geography of SARS: paradoxes and dilemmas in Toronto's health care. Journal of Ad- vanced Nursing. 2004; 45: 568-578. PMid:15012634 https : //doi . org/10.1046/j.1365-2648.2003.02958.x

[46] Shih FJ, Turale S, Lin YS, et al. Surviving a life-threatening crisis: Taiwan's nurse leaders' reflections and difficulties fighting the SARS epidemic. Journal of Clinical Nursing. 2009; 18: 3391-3400. PMid:19207797 https : //doi.org/10.1111/j.1365-2702. 20 $08.02521 . x$

[47] Synoground SG, Kellmer-Langam DM. Nursing students' attitudes towards AIDS: implications for education. Nursing Education Today. 1991; 11(3): 200-206. https : //doi.org/10.1016/0260-6 917 (91) 90060-N

[48] Bologna Working Group. A Framework for Qualifications of the European Higher Education Area. Bologna Working Group Report on Qualifications Frameworks. 2005. Available from: http://ecahe.eu/w/index.php/Framework_for_Qua lifications_of_the_European_Higher_Education_Area

[49] Houghton C, Meskell P, Delaney H, et al. Barriers and facilitators to healthcare workers' adherence with infection prevention and control (IPC) guidelines for respiratory infectious diseases: a rapid qualitative evidence synthesis. Cochrane Database of Systematic Reviews. 2020. PMid:32315451 https ://doi.org/10.1002/14651858.C D013582

[50] Singh A, Haynes M. Guest Editorial: The challenges of COVID19 in nursing education: The time for faculty leadership training is now. Nurse Education in Practice. 2020. PMid:32943174 https://doi.org/10.1016/j.nepr.2020.102831

[51] Marshall AL, Wolanskyj-Spinner A. COVID-19: Challenges and Opportunities for Educatiors and Generation Z Learners. Mayo Clinic Proceedings. 2020; 95: 1135-1137. PMid:32376100 https : //doi.org/10.1016/j.mayocp. 2020.04.015

[52] Heung YYJ, Wong KYF, Kwong WYE, et al. Severe acute respiratory syndrome outbreak promotes a strong sense of professional identity among nursing students. Nurse Education Today. 2005; 25(2): 112118. PMid:15701536 https ://doi.org/10.1016/j.nedt. 200 4.11 .003 